\title{
Relative effects of dendrometers on the estimation of diameter at breast height, stand basal area and stand volume in uneven-aged northern hardwoods
}

\author{
by François Guillemette ${ }^{1,2}$ and Marie-Claude Lambert ${ }^{1}$
}

\begin{abstract}
Four methods of estimating diameter at breast height (DBH) were used on 558 northern hardwood stems, located in 6 , 0.25 -ha plots, to compare their effects. The first method was a diameter tape reading and the second was a systematic reading, along a predefined axis, taken with a calliper. The last 2 methods were both obtained from the arithmetic mean of 2 different pairs of calliper readings taken at right angles. The first pair was directed along the major bole axis and the other pair along the minor axis. The 4 methods were compared in terms of mean tree diameter, plot basal area and plot volume. There were significant differences $(p<0.05)$ in parameter estimates among methods, and the differences varied according to species (Acer saccharum Marsh. and Betula alleghaniensis Britt.) and tree size class. Differences among methods were more evident for larger DBH classes, which contribute most to the significant differences observed for both the plot and stand basal area and volume. Overall, tree $\mathrm{DBH}$, plot basal area and plot volume provided by these 4 methods ranked in this ascending order: mean calliper reading directed along the minor axis, systematic calliper reading, mean calliper reading directed along the major axis, and diameter tape. The difference in stand basal area or volume between the estimates obtained with a systematic calliper reading and a diameter tape was $1.1 \mathrm{~m}^{2} / \mathrm{ha}$ with a mean basal area of about $21 \mathrm{~m}^{2} / \mathrm{ha}$, or $10.5 \mathrm{~m}^{3} /$ ha with a mean stand volume of $169 \mathrm{~m}^{3} / \mathrm{ha}$. Because of the magnitude of these differences, it is recommended the method of DBH estimation be specified in studies, to be careful when crossing databases or models using different methods of DBH estimation, and to always maintain the same method of DBH estimation when remeasuring a plot.
\end{abstract}

Key words: northern hardwoods, dendrometer, diameter tape, calliper, caliper, DBH measurement, basal area, volume

\section{RÉSUMÉ}

Quatre méthodes de détermination du diamètre à hauteur de poitrine ( $\mathrm{dhp}$ ) ont été prises sur 558 tiges de feuillu noble réparties dans 6 placettes de 0,25 ha pour comparer leurs effets. La première méthode consistait en une mesure prise avec un ruban diamétrique et la seconde était une mesure prise de façon systématique, selon un axe prédéterminé, avec un pied à coulisse. Les 2 dernières méthodes consistaient chacune à calculer la moyenne arithmétique d'une paire de mesures perpendiculaires prises avec le pied à coulisse : la première paire était orientée selon l'axe le plus long et la seconde paire selon laxe le plus court. Ces 4 méthodes de détermination du dhp d'un arbre ont été comparées par rapport au diamètre moyen des arbres, à la surface terrière de la placette et au volume de la placette. Il y avait des différences significatives $(p<0,05)$ entre les paramètres calculés selon ces 4 méthodes et les différences variaient selon l'espèce (Acer saccharum Marsh. et Betula alleghaniensis Britt.) et la classe de dhp. Les différences entre les méthodes étaient plus importantes pour les plus grands dhp. Ces derniers sont principalement à lorigine des différences significatives observées pour la surface terrière et le volume de la placette, ou du peuplement. De façon globale, les dhp, surfaces terrières par placette et volumes par placette obtenus par ces 4 méthodes se classent, par ordre croissant, de la manière suivante : moyenne des 2 mesures prises au pied à coulisse de la paire orientée selon laxe le plus court, mesure systématique prise au pied à coulisse, moyenne des 2 mesures prises au pied à coulisse de la paire orientée selon laxe le plus long et la mesure prise au ruban diamétrique. La différence de surface terrière ou de volume à léchelle du peuplement entre la mesure prise de façon systématique au pied à coulisse et la mesure prise au ruban diamétrique était de $1,1 \mathrm{~m}^{2} /$ ha pour un peuplement moyen de $21 \mathrm{~m}^{2} / \mathrm{ha}$, ou 10.5 $\mathrm{m}^{3} /$ ha pour un peuplement moyen de $169 \mathrm{~m}^{3} /$ ha. Étant donné l'importance de cette différence, il est recommandé de spécifier la méthode destimation du dhp dans les études, dêtre prudent lors du croisement de bases de données ou de modèles conçus avec des méthodes différentes d'estimation du dhp et de conserver la même méthode d'estimation du dhp à chaque mesurage dans une placette.

Mots clés : feuillus nobles, dendromètre, ruban diamétrique, pied à coulisse, mesure du diamètre, surface terrière, volume

\footnotetext{
${ }^{1}$ Direction de la recherche forestière, Ministère des Ressources naturelles et de la Faune du Québec, 2700 Einstein, Québec G1P 3W8.

${ }^{2}$ Corresponding author. E-mail: francois.guillemette@mrnf.gouv.qc.ca
} 


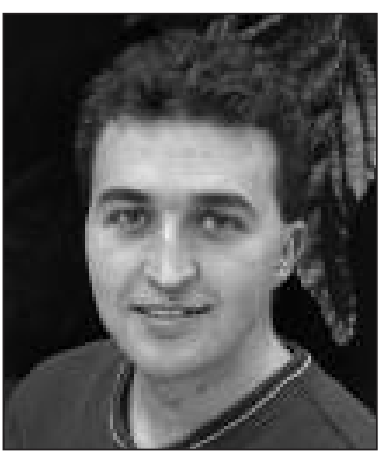

François Guillemette

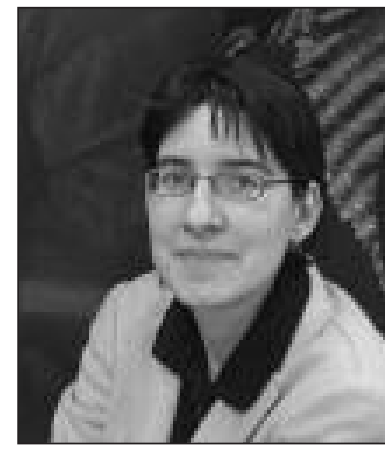

Marie-Claude Lambert

\section{Introduction}

Diameter at breast height $(\mathrm{DBH})$ is one of the most frequent and most important tree measurements taken in forestry. Along with tree species, it is a fundamental datum from which many analyses are performed and management decisions taken.

The common use of the word "diameter" in forestry usually implies that the cross-section of the bole is circular. However, this is never exactly the case, and it is often better described as a closed convex area (Fig. 1a; Matérn 1956, 1990; Chacko 1961; Williamson 1975; Kellogg and Barber 1981; Biging and Wensel 1988; Clark et al. 2000). It is more practical to define $a$ diameter as the distance between 2 parallel tangents to the closed convex area (Fig. 1b) and to define the diameter as the arithmetic mean of all possible diameters on the area (Matérn 1956). The magnitude of irregularity of the cross-section of the bole varies among species (Chacko 1961, Matérn 1990), and may increase with tree size (Moran and Williams 2002). Observations of irregular bole cross-sections are common in Québec's uneven-aged northern hardwoods.

Cross-section irregularity may result in different DBH estimations depending on the selected dendrometer, the way it is used, and the geometric relationship used to estimate mean diameter (Schenck 1905; Matérn 1956, 1990; Avery and Burkhart 2002; Elzinga et al. 2005). In Québec, diameter tapes and callipers are the most common dendrometers used in forest practice. The diameter tape is known to be a more consistent method (Avery and Burkhart 2002), and is usually preferred in permanent sample plots, where growth is system-

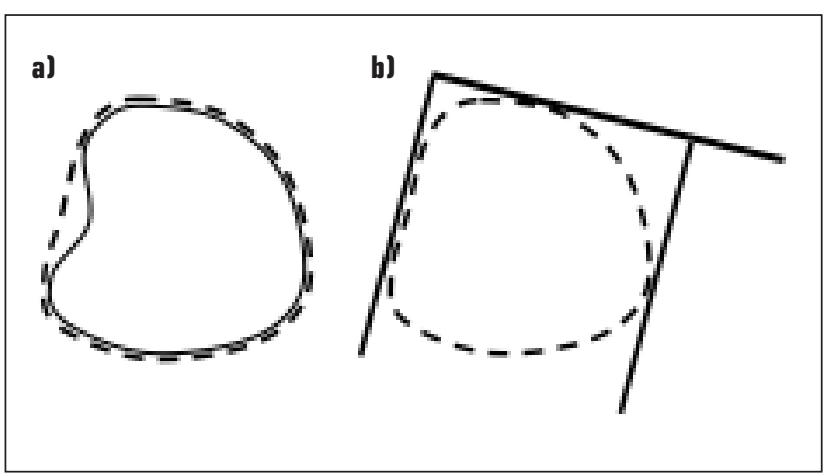

Fig. 1. The closed convex area (dashed line) of a bole cross-section (solid line) (a) and a diameter defined as the distance between 2 parallel tangents (solid lines) to the closed convex area as it is measured with a calliper (h) atically monitored. The calliper is often preferred in temporary plots for its rapidity. While a diameter can be read directly from the calliper, it is the circumference that is actually read from a diameter tape and the diameter is computed assuming a perfect circle. Two calliper readings at right angles ( $a$ and $b$ ) can be made when the stem cross-section is elliptical. An arithmetic $\left(\frac{a+b}{2}\right)$ or a geometric $(\sqrt{a b})$ mean can

then be calculated. The latter is more appropriate because it is exactly the mean diameter of an ellipse (and of a circle), but the former is easier to calculate in the field. However, most of the cruising work done with callipers in Québec is performed with only one reading along a systematic and predefined axis (MRNF 2002). This method is thought to minimize directional bias (Avery and Burkhart 2002), but it does not maximize precision at the stem level.

From the scientific literature alone, it was impossible to obtain an order of magnitude of the difference between diameter tape and calliper readings applicable to northern hardwoods in Quebec. Indeed, most publications addressed this question either from a theoretical perspective (e.g., Matérn 1956, Brickell 1970), from observations on conifers (e.g., Williamson 1975, Kellogg and Barber 1981, Biging and Wensel 1988, Matérn 1990) or with the method of averaging 2 calliper readings at right angles (e.g., Binot et al. 1995, Moran and Williams 2002). Moreover, these studies reported a dendrometer's effect at the stem level, but not how it affects some variables computed at the stand level, such as basal area and volume. The only 2 publications found in relation to northern hardwoods (Binot et al. 1995, Moran and Williams 2002) had studied only a few large stems, which are the most likely to have an irregular cross-section. However, such large stems often represent a significant proportion of the stand basal area and volume in uneven-aged northern hardwoods. Finally, only few studies (Chacko 1961; Matérn 1956, 1990) addressed the case of using a systematic calliper reading, as is in common use in Québec.

The main objective of the present study is to compare and quantify the effects of different DBH measurements, taken with a diameter tape and a calliper, on stem diameter and stand basal area and volume in Québec's uneven-aged northern hardwood forest.

\section{Method}

The study was carried out in 6 uneven-aged northern hardwood stands located on 3 sites in southern Québec (Fig. 2). These stands are part of networks of experimental sites established to study the effects of selection cutting (e.g., Bédard and Majcen 2001, 2003; Majcen et al. 2005). The stands located in Sainte-Véronique (SV, $\left.46.603^{\circ} \mathrm{N}, 74.907^{\circ} \mathrm{W}\right)$ are within the sugar maple (Acer saccharum Marsh.)-yellow birch (Betula alleghaniensis Britt.) bioclimatic domain, while those located at Duchesnay (DU, $46.876^{\circ} \mathrm{N}, 71.645^{\circ} \mathrm{W}$ ) and Mitchinamecus (MI, $47.252^{\circ} \mathrm{N}, 75.158^{\circ} \mathrm{W}$ ) are within the yellow birch-balsam fir bioclimatic domain (Robitaille and Saucier 1998). The mean annual temperature ranges from $2.5^{\circ} \mathrm{C}$ to $3.4^{\circ} \mathrm{C}$ and the mean annual precipitation from 1000 $\mathrm{mm}$ to $1350 \mathrm{~mm}$ (Robitaille and Saucier 1998, Environment Canada 2007).

Five of the 6 stands are typical sugar maple -yellow birch stands, and the other one is of the sugar maple-yellow birch-American beech (Fagus grandifolia Ehrh.) type. Sugar 


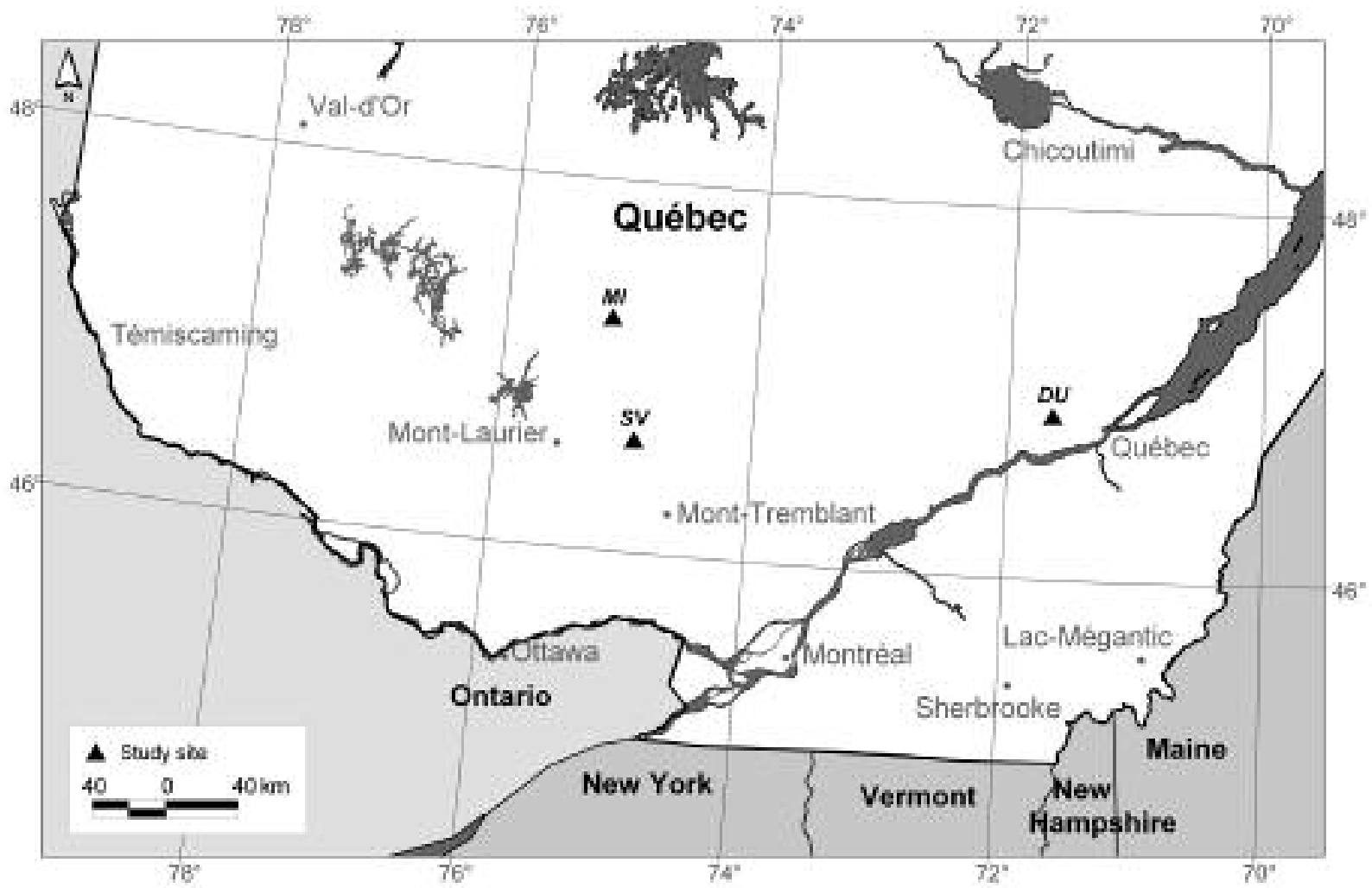

Fig. 2. Location of the study sites.

maple and yellow birch together comprised $74 \%$ to $99 \%$ of the stands' basal area. Merchantable (DBH $>90 \mathrm{~mm}$ ) basal areas of these stands range from 16.7 to $26.8 \mathrm{~m}^{2} /$ ha when computed with $\mathrm{DBH}$ taken with a diameter tape. These stands developed on glacial tills, with slopes ranging from $2 \%$ to $10 \%$.

One 0.25-ha square plot was established in each stand. Within the plot, all trees with $\mathrm{DBH}$, taken with a diameter tape, equal to or greater than $91 \mathrm{~mm}$ were numbered and described. The DBH location was marked on the tree prior to measuring. Six DBH measurements, to the nearest millimetre, were taken on every tree for the purposes of the present study. These measurements were performed by experienced and meticulous observers. The first measurement was obtained with a steel diameter tape $\left(\mathrm{DBH}_{\text {tape }}\right)$ and the other 5 were different diameter readings taken with an aluminium calliper scaled from 0 to $650 \mathrm{~mm}$. A calliper reading was taken along a predefined and randomly selected axis for the entire plot, which is referred to as the systematic reading $\left(\mathrm{DBH}_{\text {sys }}\right)$. There was no evidence of a directional bias within these plots. The following 4 readings on the cross-section were the minor axis $\left(\mathrm{DBH}_{\text {min }}\right)$, a reading perpendicular to this minor axis $\left(\mathrm{DBH}_{\text {pmin }}\right)$, the major axis $\left(\mathrm{DBH}_{\max }\right)$ and a reading perpendicular to this major axis $\left(\mathrm{DBH}_{\mathrm{pmax}}\right.$, Fig. 3). The $\mathrm{DBH}_{\text {pmax }}$ reading was missing at the MI site. No more than one tree per plot was rejected due to having a $\mathrm{DBH}_{\max }$ larger than the maximum calliper scale. With the calliper, the average $\mathrm{DBH}$ of the last 2 pairs of readings $\left(\left[\mathrm{DBH}_{\min }\right.\right.$, $\mathrm{DBH}_{\text {pmin }}$ and $\left.\mathrm{DBH}_{\text {max }}, \mathrm{DBH}_{\text {pmax }}\right]$ ) were computed using the arithmetic mean, and are referred to as $\mathrm{DBH}_{\mathrm{mmin}}$ and $\mathrm{DBH}_{\text {mmax }}$, respectively. No practical differences were expected when using the geometric or the quadratic means instead of the arithmetic mean (Matérn 1956, 1990; Moran and Williams 2002) and some preliminary analyses with the geometric and quadratic means supported these expectations.

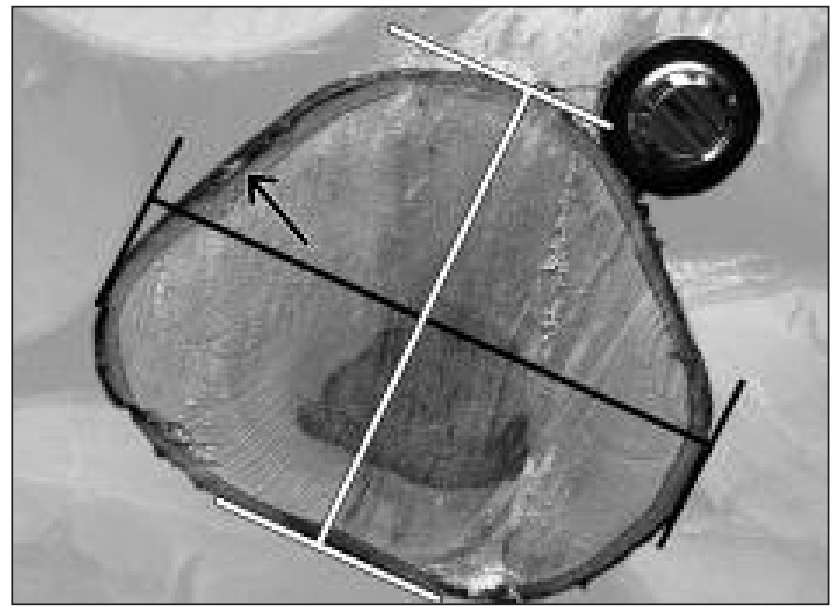

Fig. 3. Measures of $\mathrm{DBH}_{\text {tape }}$ (circumference, $304 \mathrm{~mm}$ ), $\mathrm{DBH}_{\max }$ (black line, $327 \mathrm{~mm}$ ) and $\mathrm{DBH}_{\text {min }}$ (white line, $268 \mathrm{~mm}$ ) on an irregular bole cross-section of yellow birch. In this particular case, $\mathrm{DBH}_{\max }=\mathrm{DBH}_{\mathrm{pmin}}, \mathrm{DBH}_{\min }=\mathrm{DBH}_{\text {pmax }}$ and $\mathrm{DBH}_{\operatorname{mmax}}=\mathrm{DBH}_{\operatorname{mmin}}$ $=297.5 \mathrm{~mm}$. Note the presence of a concave region (arrow). 
A total of 558 trees were measured, including 448 sugar maple trees and 77 yellow birch trees. Some tree-level descriptive statistics are shown in Table 1. Gross merchantable volume was computed from local height-DBH relations and the Perron (1985) general stock table. This stock table was developed from $\mathrm{DBH}$ measured with a calliper reading $(\mathrm{mm})$ taken on the bole side facing the plot center, which means in a systematic manner (MTF 1974). Perron's stock table was preferred to the one proposed by Fortin et al. (2007) because of a smaller bias with sugar maple and yellow birch. Moreover, error propagation was not an issue in the present study, contrary to the study of Fortin et al. (2007).

Tree $\mathrm{DBH}$, plot basal area and plot volume data were analysed using repeated measurements of analysis of variance. For the first model with $\mathrm{DBH}$, the tree $\mathrm{DBH}$ measurement method is the repeated effect, because the 4 methods are all applied to the same trees. In order to model the correlation among methods applied to the same tree, the covariance structure among methods was specified using the repeated statement in the MIXED procedure of the SAS system (SAS Institute Inc. 2004). The unstructured covariance option was used in the absence of an evident pattern of correlation among methods. Trees were defined as subjects, while plot and site were specified as random effects. The model also included fixed effects of tree species (sugar maple and yellow birch) and DBH class. Trees were grouped in size classes based on the tape measurement: poles from $91 \mathrm{~mm}$ to 230 $\mathrm{mm}$, small sawlogs from $231 \mathrm{~mm}$ to $390 \mathrm{~mm}$ and large sawlogs from $391 \mathrm{~mm}$ to $605 \mathrm{~mm}$. For the second model with plot basal area, 4 basal areas were computed using the 4 different $\mathrm{DBH}$ measurements of each tree of commercial species, obtained by different measurement methods. These were summed to compute plot basal area per method. The plot basal area is then the repeated effect, because the 4 methods are all applied to the same plots. In order to model the correlation among methods, the Toeplitz covariance structure of the MIXED procedure was used, because the unstructured covariance did not converge. The methodology applied to plot basal area was also used for the third model with plot volume.

Tests of the random part were conducted at a level of significance such as $\alpha=30 \%$, as suggested by Milliken and Johnson (1993). The variance parameter estimated to be zero or near zero, was included in the residual error term. The normality and homogeneity of variance hypotheses were verified. More precisely, they estimate the marginal means for a balanced population. A simulation-based method was used to adjusted $p$ values for pairwise comparisons between $\mathrm{DBH}$ measurement methods (Hsu 1996, Westfall et al. 1999).

\section{Results}

\section{Tree DBH}

Mean tree DBH was significantly different $(p<0.05)$ among $\mathrm{DBH}$ size classes and among measurement methods with a simple effect, and in interaction with species or size class (Table 2).

The highest $\mathrm{DBH}$ observed on yellow birch was with $\mathrm{DBH}_{\text {mmax }}$ and $\mathrm{DBH}_{\text {tape }}$ (Table 3 ). These were significantly

Table 1. Descriptive statistics in millimetres. Mean values and standard deviations (Std) were computed from the number of trees ( $\mathrm{n}$ )

\begin{tabular}{|c|c|c|c|c|c|c|c|c|c|c|c|c|}
\hline \multirow[b]{2}{*}{ Site } & \multirow{2}{*}{$\begin{array}{l}\text { Plot BA } \\
\text { (volume) }\end{array}$} & \multirow{2}{*}{$\begin{array}{l}\text { Measurement } \\
\text { method }\end{array}$} & \multicolumn{5}{|c|}{ Yellow birch } & \multicolumn{5}{|c|}{ Sugar maple } \\
\hline & & & $\mathbf{n}$ & Mean & Std & Min. & Max. & $\mathbf{n}$ & Mean & Std & Min. & Max. \\
\hline \multirow[t]{8}{*}{ DU } & 21.0 & $\mathrm{DBH}_{\operatorname{mmax}}$ & 7 & 316 & 112 & 190 & 466 & 114 & 208 & 80 & 94 & 588 \\
\hline & $(162)$ & $\mathrm{DBH}_{\mathrm{mmin}}$ & 7 & 301 & 100 & 181 & 429 & 114 & 204 & 79 & 92 & 584 \\
\hline & & $\mathrm{DBH}_{\text {sys }}$ & 7 & 310 & 112 & 186 & 460 & 114 & 205 & 80 & 96 & 590 \\
\hline & & $\mathrm{DBH}_{\text {tape }}^{\text {sys }}$ & 7 & 315 & 108 & 188 & 458 & 114 & 210 & 80 & 95 & 589 \\
\hline & 25.7 & $\mathrm{DBH}_{\operatorname{mmax}}^{\text {tape }}$ & 30 & 363 & 120 & 127 & 555 & 45 & 176 & 74 & 92 & 388 \\
\hline & $(225)$ & $\mathrm{DBH}_{\operatorname{mmin}}^{\operatorname{mmax}}$ & 30 & 352 & 115 & 122 & 539 & 45 & 172 & 71 & 91 & 382 \\
\hline & & $\mathrm{DBH}_{\text {sys }}$ & 30 & 358 & 114 & 118 & 543 & 45 & 173 & 69 & 94 & 363 \\
\hline & & $\mathrm{DBH}_{\text {tape }}^{\text {sys }}$ & 30 & 363 & 119 & 127 & 554 & 45 & 178 & 73 & 95 & 385 \\
\hline \multirow[t]{8}{*}{ SV } & 20.5 & $\mathrm{DBH}_{\operatorname{mmax}}$ & 2 & 300 & 248 & 125 & 476 & 64 & 290 & 104 & 107 & 548 \\
\hline & (184) & $\mathrm{DBH}_{\operatorname{mmin}}^{\operatorname{mmax}}$ & 2 & 290 & 234 & 125 & 456 & 64 & 280 & 99 & 106 & 498 \\
\hline & & $\mathrm{DBH}_{\text {sys }}$ & 2 & 299 & 238 & 130 & 467 & 64 & 281 & 100 & 103 & 522 \\
\hline & & $\mathrm{DBH}_{\text {tape }}^{\text {sys }}$ & 2 & 302 & 248 & 126 & 477 & 64 & 293 & 104 & 109 & 531 \\
\hline & 21.3 & $\mathrm{DBH}_{\operatorname{mmax}}^{\text {tape }}$ & 0 & - & - & - & - & 77 & 270 & 105 & 94 & 596 \\
\hline & $(183)$ & $\mathrm{DBH}_{\operatorname{mmin}}$ & 0 & - & - & - & - & 77 & 263 & 100 & 91 & 596 \\
\hline & & $\mathrm{DBH}_{\text {sys }}$ & 0 & - & - & - & - & 77 & 262 & 99 & 97 & 569 \\
\hline & & $\mathrm{DBH}_{\text {tape }}^{\text {sys }}$ & 0 & - & - & - & - & 77 & 272 & 104 & 95 & 605 \\
\hline \multirow[t]{8}{*}{ MI } & 16.7 & $\mathrm{DBH}_{\operatorname{mmax}}$ & 17 & - & - & - & - & 71 & - & - & - & - \\
\hline & $(120)$ & $\mathrm{DBH}_{\operatorname{mmin}}$ & 17 & 315 & 105 & 122 & 488 & 71 & 192 & 84 & 96 & 450 \\
\hline & & $\mathrm{DBH}_{\text {sys }}^{\mathrm{mm}}$ & 17 & 318 & 110 & 121 & 509 & 71 & 192 & 85 & 92 & 463 \\
\hline & & $\mathrm{DBH}_{\text {tape }}^{\text {sys }}$ & 17 & 324 & 110 & 125 & 509 & 71 & 197 & 86 & 96 & 477 \\
\hline & 26.8 & $\mathrm{DBH}_{\operatorname{mmax}}^{\text {tape }}$ & 21 & - & - & - & - & 77 & - & - & - & - \\
\hline & (202) & $\mathrm{DBH}_{\operatorname{mmin}}^{\operatorname{mmax}}$ & 21 & 298 & 103 & 93 & 523 & 77 & 242 & 115 & 103 & 584 \\
\hline & & $\mathrm{DBH}_{\text {sys }}^{\mathrm{mmmn}}$ & 21 & 302 & 105 & 96 & 558 & 77 & 243 & 115 & 107 & 548 \\
\hline & & $\mathrm{DBH}_{\text {tape }}^{\text {sys }}$ & 21 & 305 & 105 & 96 & 537 & 77 & 249 & 120 & 105 & 601 \\
\hline
\end{tabular}

BA: basal area $\left(\mathrm{m}^{2} / \mathrm{ha}\right)$, Min.: minimum value, Max.: maximum value. These BA and volumes $\left(\mathrm{m}^{3} / \mathrm{ha}\right)$ were computed with the DBH estimated using a diameter tape. 
Table 2. Results of the repeated measurements analysis performed on the tree data

\begin{tabular}{lrrr}
\hline Fixed effects & Df & F value & \multicolumn{1}{c}{$\boldsymbol{p}$} \\
\hline Species & 1 & 3.51 & 0.0615 \\
Size class & 2 & 680.46 & $<\mathbf{0 . 0 0 0 1}$ \\
Species $\times$ size class & 2 & 0.50 & 0.6053 \\
Method & 3 & 264.57 & $<\mathbf{0 . 0 0 0 1}$ \\
Species $\times$ method & 3 & 3.82 & $\mathbf{0 . 0 1 0 1}$ \\
Size class $\times$ method & 6 & 30.10 & $<\mathbf{0 . 0 0 0 1}$ \\
Species $\times$ size class $\times$ method & 6 & 0.95 & 0.4565 \\
\hline
\end{tabular}

There was no significant plot and stand random effect at $\alpha=30 \%$. Df $=$ degrees of freedom.

Table 3. Mean DBH (mm) and standard error per species and method

\begin{tabular}{llcc}
\hline Species & Method & Estimate & $\begin{array}{c}\text { Standard } \\
\text { Error }\end{array}$ \\
\hline Yellow birch & $\mathrm{DBH}_{\text {mmax }}$ & $317.5 \mathrm{a}$ & 5.3 \\
& $\mathrm{DBH}_{\text {mmin }}$ & $308.5 \mathrm{c}$ & 5.2 \\
& $\mathrm{DBH}_{\text {sys }}$ & $312.7 \mathrm{~b}$ & 5.2 \\
& $\mathrm{DBH}_{\text {tape }}$ & $317.8 \mathrm{a}$ & 5.3 \\
Sugar maple & $\mathrm{DBH}_{\text {mmax }}$ & $307.1 \mathrm{e}$ & 2.8 \\
& $\mathrm{DBH}_{\text {mmin }}$ & $298.0 \mathrm{f}$ & 2.8 \\
& DBH $_{\text {sys }}$ & $298.7 \mathrm{f}$ & 2.8 \\
& $\mathrm{DBH}_{\text {tape }}$ & $308.6 \mathrm{~d}$ & 2.8 \\
\hline
\end{tabular}

Estimates followed by a different letter within a species are significantly different at $\alpha=0.05$.

higher than $\mathrm{DBH}_{\text {sys }}$ and $\mathrm{DBH}_{\text {mmin }}$, with a difference ranging from $5 \mathrm{~mm}$ to $9 \mathrm{~mm}$. Results for sugar maple were slightly different, with $\mathrm{DBH}_{\text {tape }}$ having the highest value. It was $1.5 \mathrm{~mm}$ higher than $\mathrm{DBH}_{\operatorname{mmax}}$, which was significantly higher than $\mathrm{DBH}_{\text {sys }}$ and $\mathrm{DBH}_{\text {mmin }}$ by about $8 \mathrm{~mm}$ to $9 \mathrm{~mm}$. There were no significant differences between these last 2 measurements.

Results by size class showed the same general tendency among methods, but the magnitude of these differences was higher for larger size classes (Table 4). For pole-size stems, only difference between $\mathrm{DBH}_{\text {tape }}$ and $\mathrm{DBH}_{\text {mmin }}(4.5 \mathrm{~mm}$ or
Table 4. Adjusted mean DBH (mm) and standard error per DBH class and method

\begin{tabular}{llcc}
\hline DBH class & Method & Estimate & $\begin{array}{c}\text { Standard } \\
\text { Error }\end{array}$ \\
\hline Poles & DBH $_{\text {mmax }}$ & $166.6 \mathrm{fg}$ & 5.7 \\
$(91-230 \mathrm{~mm})$ & $\mathrm{DBH}_{\text {mmin }}$ & $163.6 \mathrm{~g}$ & 5.5 \\
& $\mathrm{DBH}_{\text {sys }}$ & $164.0 \mathrm{fg}$ & 5.5 \\
& $\mathrm{DBH}_{\text {tape }}$ & $168.1 \mathrm{f}$ & 5.6 \\
& & $305.7 \mathrm{~cd}$ & 4.1 \\
Small sawlogs & $\mathrm{DBH}_{\text {mmax }}$ & $298.5 \mathrm{e}$ & 3.9 \\
$(231-390 \mathrm{~mm})$ & $\mathrm{DBH}_{\text {mmin }}$ & $302.3 \mathrm{~d}$ & 3.9 \\
& $\mathrm{DBH}_{\text {sys }}$ & $307.5 \mathrm{c}$ & 4.0 \\
& $\mathrm{DBH}_{\text {tape }}$ & & \\
& $\mathrm{DBH}_{\text {mmax }}$ & $464.7 \mathrm{a}$ & 5.7 \\
Large sawlogs & $\mathrm{DBH}_{\text {mmin }}$ & $447.7 \mathrm{~b}$ & 5.6 \\
(391-605 mm) & $\mathrm{DBH}_{\text {sys }}$ & $450.8 \mathrm{~b}$ & 5.6 \\
& $\mathrm{DBH}_{\text {tape }}$ & $464.1 \mathrm{a}$ & 5.7 \\
\hline
\end{tabular}

Estimates followed by a different letter within a DBH class are significantly different at $\alpha=0.05$.

$2.7 \%)$ was significant. For small sawlog-size stems, $\mathrm{DBH}_{\text {tape }}$ was significantly higher than both the $\mathrm{DBH}_{\text {mmin }}(+9.0 \mathrm{~mm}$ or $2.9 \%)$ and $\mathrm{DBH}_{\text {sys }}(+5.2 \mathrm{~mm}$ or $1.7 \%)$. The $\mathrm{DBH}_{\operatorname{mmax}}$ was only significantly higher than the $\mathrm{DBH}_{\text {mmin }}(+7.2 \mathrm{~mm}$ or $2.4 \%)$. Finally, for large sawlog-size stems, $\mathrm{DBH}_{\operatorname{mmax}}$ and $\mathrm{DBH}_{\text {tape }}$ were significantly larger than $\mathrm{DBH}_{\text {sys }}$ and $\mathrm{DBH}_{\text {mmin }}$. The mean difference between these 2 groups was about 13 $\mathrm{mm}$ to $17 \mathrm{~mm}(3.0 \%-3.7 \%)$.

\section{Plot basal area}

The measurement method had a significant effect $(p=0.0007$, $\mathrm{F}$ value $=41.07,3$ degrees of freedom) on the plot basal area estimates. The different estimates (Table 5) are ranked in the same order as are the DBH results (Tables 3 and 4). The basal area computed from data with the $\mathrm{DBH}_{\text {tape }}$ was significantly higher than that computed from data obtained by the calliper methods. In practical terms, stand basal area computed with $\mathrm{DBH}_{\text {tape }}\left(22.0 \mathrm{~m}^{2} / \mathrm{ha}\right)$ was about $0.3,1.1$ and $1.4 \mathrm{~m}^{2} /$ ha higher than that computed with $\mathrm{DBH}_{\text {mmax }}\left(21.7 \mathrm{~m}^{2} / \mathrm{ha}\right), \mathrm{DBH}_{\text {sys }}$ $\left(20.9 \mathrm{~m}^{2} / \mathrm{ha}\right)$ and $\mathrm{DBH}_{\mathrm{mmin}}\left(20.6 \mathrm{~m}^{2} / \mathrm{ha}\right)$, respectively. Moreover, basal area computed from $\mathrm{DBH}_{\operatorname{mmax}}$ was significantly higher than that computed from $\mathrm{DBH}_{\text {sys }}$ and $\mathrm{DBH}_{\text {mmin }}$.

Table 5. Number of observations (n), adjusted mean basal area, adjusted mean volume and standard error per method

\begin{tabular}{|c|c|c|c|c|c|c|c|}
\hline \multirow[b]{3}{*}{ Method } & \multicolumn{4}{|c|}{ Basal area } & \multicolumn{3}{|c|}{ Volume } \\
\hline & & Estimate & Standard error & \multirow{2}{*}{$\begin{array}{c}\text { Estimate } \\
\left(\mathrm{m}^{2} / \mathrm{ha}\right)\end{array}$} & Estimate & Standard error & \multirow{2}{*}{$\begin{array}{l}\text { Estimate } \\
\left(\mathrm{m}^{3} / \mathrm{ha}\right)\end{array}$} \\
\hline & $\mathbf{n}$ & \multicolumn{2}{|c|}{$\left(\mathrm{m}^{2} /\right.$ plot $)$} & & \multicolumn{2}{|c|}{$\left(\mathrm{m}^{3} /\right.$ plot $)$} & \\
\hline $\mathrm{DBH}_{\operatorname{mmax}}$ & 4 & $5.44 \mathrm{~b}$ & 0.37 & 21.7 & $44.25 \mathrm{a}$ & 3.56 & 177.0 \\
\hline $\mathrm{DBH}_{\operatorname{mmin}}$ & 6 & $5.15 c$ & 0.37 & 20.6 & $41.35 \mathrm{~b}$ & 3.56 & 165.4 \\
\hline $\mathrm{DBH}_{\text {sys }}$ & 6 & $5.23 c$ & 0.37 & 20.9 & $42.21 \mathrm{~b}$ & 3.56 & 168.9 \\
\hline $\mathrm{DBH}_{\text {tape }}^{\mathrm{sys}}$ & 6 & $5.50 \mathrm{a}$ & 0.37 & 22.0 & $44.82 \mathrm{a}$ & 3.56 & 179.3 \\
\hline
\end{tabular}

Estimates followed by a different letter are significantly different at $\alpha=0.05$. 


\section{Plot volume}

The measurement method had a significant effect $(p=$ $0.0009, \mathrm{~F}$ value $=33.82,3$ degrees of freedom) on plot volume estimates. The different estimates for each method (Table 5) ranked in the same order as the $\mathrm{DBH}$ and basal area results. Volumes computed with data from $\mathrm{DBH}_{\text {tape }}\left(179.3 \mathrm{~m}^{3} / \mathrm{ha}\right)$ or $\mathrm{DBH}_{\text {mmax }}\left(177.0 \mathrm{~m}^{3} / \mathrm{ha}\right)$ were significantly higher than those computed using $\mathrm{DBH}_{\text {sys }}\left(168.9 \mathrm{~m}^{3} / \mathrm{ha}\right)$ and $\mathrm{DBH}_{\text {mmin }}(165.4$ $\mathrm{m}^{3} / \mathrm{ha}$ ). Of particular interest in this study, the stand volume computed with $\mathrm{DBH}_{\text {tape }}$ was $10.45 \mathrm{~m}^{3} /$ ha higher than that computed using $\mathrm{DBH}_{\text {sys }}^{\text {tape }}\left(168.9 \mathrm{~m}^{3} / \mathrm{ha}\right)$.

\section{Discussion}

Although the method of DBH estimation is rarely reported in hardwood studies (e.g., Erdmann and Oberg 1973, Crow et al 1981, Strong et al. 1995, Schuler 2004), it has a significant effect on mean DBH, and especially on stand basal area and volume. As also reported by Moran and Williams (2002), the magnitude of this effect varies among species, due to different cross-sectional shapes, and is larger for larger stems, which tend to be more irregular in cross-section. Although the differences in mean $\mathrm{DBH}$ among methods were small in this study (0 to $11 \mathrm{~mm}$, Table 3 ), the effects on stand-level variables represented differences up to $1.4 \mathrm{~m}^{2} / \mathrm{ha}$ in basal area or $13.9 \mathrm{~m}^{3} /$ ha in volume (Table 5).

From this study alone, it is difficult to identify the most precise method to estimate a tree's $\mathrm{DBH}$, basal area or volume, because trees were not cut down to measure their exact crosssectional area. A more detailed and specific study involving precise measurements of the cut area of cross-section of boles could bring answers to this remaining question. However, diameter tape is known to be a more consistent method (Avery and Burkhart 2002). Random readings with the calliper are more likely to be negatively biased if the observer adjusts the direction of the calliper to avoid protruding ridges of bark or other bumps (Matérn 1990). Methods involving the maximum $\left(\mathrm{DBH}_{\operatorname{mmax}}\right)$ or minimum $\left(\mathrm{DBH}_{\operatorname{mmin}}\right) \mathrm{DBH}$ are likely to be positively and negatively biased, respectively, especially with irregular bole cross-section (Matérn 1956, 1990).

A clear result from this study is that bole cross-sections of the studied species are generally irregular (Fig. 3) and rarely circular or elliptical. The problem of answering the question of "what is the true DBH" in this context is due to the use a concept (diameter) relating to a circle that does not exist (Matérn 1956, 1990). However, this concept remains useful from a practical perspective, although not formally adequate. This problem can be overcome by the use of empirical relationships between a specific DBH measurement and other concepts, such as standing or lumber volumes, as long as the methods of measuring DBH used for model development and applications are consistent.

This paper focused on measurement differences due to the selected dendrometer and measurement method. However, there are other important causes of DBH differences to consider, including recording errors, divergences in dendrometer placement from the plane perpendicular to the tree axis, placement above or below the 1.3-m height, difference in tape tension or calliper pressure, imperfect instruments, and the nature of the instructions (Matérn 1956, 1990; Elzinga et al. 2005).

\section{Conclusion}

The most important implications to take from this study are the importance of stipulating the method of DBH estimation in every forest inventory, and the necessity to be careful when combining data gathered using different methods of measuring DBH. For example, we refer to cases of mixing data coming from permanent plots, usually measured with a diameter tape, and temporary plots, usually measured with a calliper. Our recommendation also applies to the methods of measuring $\mathrm{DBH}$ used for model development and applications. Models may have unknown bias and precision when applied to data collected with a different method. The same method of $\mathrm{DBH}$ measurement should be used when remeasuring plots to minimize the effects of measurement bias on the growth estimates. Finally, some additional studies could be carried out to quantify the magnitude of the bias in other contexts and to better explain the causes of differences between methods.

\section{Acknowledgments}

The authors thank Jocelyn Hamel, Étienne Boulay, JeanFrançois Leblond, Éric Labrecque and Pierre Laurent for their co-operation in field measurements and data processing. Thanks are also extended to Sebastien Meunier for his useful comments on the draft of this text, and to both Maripierre Jalbert and Denis Hotte for preparing figures. We thank John Kershaw and 2 anonymous reviewers for their thorough review of this paper.

\section{References}

Avery, T.E. and H.E. Burkhart. 2002. Forest measurement. $5^{\text {th }}$ ed. McGraw Hill, NY. 456 p.

Bédard, S. and Z. Majcen. 2001. Ten-year response of sugar maple-yellow birch-beech stands to selection cutting in Québec. North. J. Appl. For. 18(4): 119-126.

Bédard, S. and Z. Majcen. 2003. Growth following single-tree selection cutting in Québec northern hardwoods. For. Chron. 79: 898-905. Biging, G.S. and L.C. Wensel. 1988. The effect of eccentricity on the estimation of basal area and basal area increment of coniferous trees. For. Sci. 34: 621-633.

Binot, J.-M., D. Pothier and J. Lebel. 1995. Comparison of relative accuracy and time requirement between the caliper, the diameter tape and an electronic tree measuring fork. For. Chron. 71: 197-200. Brickell, 1970. More on diameter tape and calipers. J. For. 68(3): 169-170.

Chacko, V.J. 1961. A study of the shape of cross section of stems and the accuracy of calliper measurement. Ind. Forester 87: 758-762.

Clark, N.A., R.H. Wynne and D.L. Schmoldt. 2000. A review of past research on dendrometers. For. Sci. 46(4): 570-576.

Crow, T.R., C.H. Tubbs, R.D. Jacobs and R.R. Oberg. 1981. Stocking and structure for maximum growth in sugar maple selection stands. USDA For. Serv., Res. Pap. NC-109. 16 p.

Elzinga, C., R.C. Shearer and G. Elzinga. 2005. Observer variation on tree diameter measurements. West. J. Appl. For. 20(2): 134-137. Environment Canada. 2007. Centre de ressources en impacts et adaptation au climat et à ses changements [on line]. Available at http://www.criacc.qc.ca/index_e.html [accessed on 20 August 2007]. Erdmann, G.G. and R.R. Oberg. 1973. Fifteen-year results from six cutting methods in second-growth northern hardwoods. USDA For. Serv. Res. Pap. NC-100. 12 p.

Fortin, M., J. DeBlois, S. Bernier and G. Blais. 2007. Mise au point d'un tarif de cubage général pour les forêts québécoises : une approche pour mieux évaluer l'incertitude associée aux prévisions. For. Chron. 83(5): 754-765. 
Hsu, J.C. 1996. Multiple comparisons: theory and methods. Chapman and Hall, London, UK. 277 p.

Kellogg, R.M. and F.J. Barber. 1981. Stem eccentricity in coastal western hemlock. Can. J. For. Res. 11: 714-718.

Majcen, Z., S. Bédard and S. Meunier. 2005. Accroissement et mortalité quinze ans après la coupe de jardinage dans quatorze érablières du Québec méridional. Gouv. du Québec, min. Ress. nat. et Faune, Dir. rech. for., Mémoire de recherche $\mathrm{n}^{\circ} 148.39$ p.

Matérn, B. 1956. On the geometry of the cross-section of a stem. Meddelanden Från Statens Skogsforskningsinstitut 46(11):1-28.

Matérn, B. 1990. On the shape of the cross-section of a tree stem. An empirical study of the geometry of mensurational methods. Swedish Univ. Of Agric., Section of For. Biometry. Umeå, Sweden. 47 p. Milliken, G.A. and D.E. Johnson. 1993. Analysis of messy data. Vol. 1. Designed experiments. Chapman \& Hall/CRC Press, New York. 498 p. Moran, L.A and R.A. Williams. 2002. Comparison of three dendrometers in measuring diameter at breast height. North. J. Appl. For. 19: 28-33.

[MRNF] Ministère des Ressources naturelles et Faune. 2002. Normes d'inventaire forestier. Placettes-échantillons temporaires. Gouv. du Québec, min. des Ress. nat. et Faune, Dir. des inv. for. 231 p. [MTF]. Ministère des Terres et Forêts. 1974. Tarifs de cubage d'utilisation - cueillette des données. Min. des Terres et Forêts, Ser. de l'inven. for. $26 \mathrm{p}$.
Perron, J.-Y. 1985. Tarif de cubage général. Volume marchand brut. $2^{\mathrm{e}}$ publication. Gouv. du Québec, min de l'Éner. et des Ress., Ser. de l'inven. for. $55 \mathrm{p}$.

Robitaille, A. and J.-P. Saucier. 1998. Paysages régionaux du Québec méridional. Gouv. du Québec, min. Ress. nat. 213 p.

SAS Institute Inc. 2004. SAS/STAT 9.1 User's Guide. SAS Institute Inc. Cary, NC. 5121 p.

Schenck, C.A. 1905. Forest mensuration. The Univ. Press, Sewanee, TN. 71 p.

Schuler, T.M. 2004. Fifty years of partial harvesting in a mixed mesophytic forest: composition and productivity. Can. J. For. Res. 34: 985-997.

Strong, T.F., G.G. Erdmann and J.N. Niese. 1995. Forty years of alternative management practices in second-growth, pole-size northern hardwoods. I. Tree quality development. Can. J. For. Res. 25: 1173-1179.

Westfall, P.H., R.D. Tobias, D. Rom, R.D. Wolfinger and Y. Hochberg. 1999. Multiple comparisons and multiple tests using the SAS system. SAS Institute Inc., Cary, NC. 416 p.

Williamson, R.L. 1975. Out-of-roundness in Douglas-fir stems. For. Sci. 21(4): 365-370. 